\title{
ВОДНЫЙ ТУРИЗМ В ПРИБАЙКАЛЬЕ: ВОПРОСЫ ОРГАНИЗАЦИИ СТРАХОВОЙ ЗАЩИТЫ ТУРИСТОВ
}

\begin{abstract}
АНнотАция. Статья посвящена актуальным вопросам формирования страховой защиты туристов как особой категории субъектов, подверженных разнообразным рискам. Проблема обеспечения безопасности похода и его участников стоит перед его организаторами, самими туристами и иными заинтересованными лицами. Между тем, водный туризм имеет некоторые особенности и разные цели, которые влияют на объем формируемого страхового покрытия. Особое внимание автором уделено страхованию лиц, занимающихся спортивным водным туризмом (выявлены присущие ему особенности и существующие проблемы реализации), а также страхованию риска расходов, связанных с проведением поисково-спасательных работ. В работе представлены основные мероприятия, которые могут быть реализованы страховщиками, представленными в регионе, с целью популяризации и дальнейшего развития страхования в сфере водного туризма. В качестве туристской дестинации выбрано Прибайкалье, имеющее разнообразные водные рекреационные ресурсы, являющиеся для данного географического района одним из наиболее ценных природных богатств.

кЛЮчЕВЫЕ словА. Прибайкалье; туризм; водный туризм; страхование; страхование туристов; страхование от несчастных случаев; поисково-спасательные работы.

ИНФОРМАЦИя О СТАТЬЕ. Дата поступления 22 января 2018 г.; дата принятия к печати 19 марта 2018 г.; дата онлайн-размещения 09 апреля 2018 г.
\end{abstract}

M. N. Stepanova Baikal State University, Irkutsk, Russian Federation

\section{WATER TOURISM IN BAIKAL REGION: ISSUES ON ORGANIZATION OF TOURIST INSURANCE COVERAGE}

\begin{abstract}
The article is devoted to the topical issues of insurance coverage formation for tourists as a special category of customers subject to various risks. The problem of ensuring a touring hike and its participants safety involves its organizers, tourists themselves, and other interested persons. Meanwhile, the water tourism has some features and different purposes that affect the amount of insurance coverage to be formed. The author gives special attention to the insurance of the people engaged in sport water tourism (he reveals the peculiarities and existing problems of it's implementation), as well as to the insurance of the cost risk associated with conducting the search and rescue operations. The paper presents the main activities that can be implemented by insurers that are represented in the region, in terms of popularizing and further developing the insurance in the field of water tourism. The Baikal Region is chosen as a tourist destination that has a variety of water recreational resources, which is one of the most valuable natural resources in this geographical region.
\end{abstract}

KEYWORDS. The Baikal Region; tourism; water tourism; insurance; insurance of tourists; accident insurance; search and rescue operations.

ARTICLE INFO. Received January 22, 2018; accepted March 19, 2018; available online April 09, 2018.

\section{Baikal Research Journal}


Водный туризм - разновидность туризма, направленного на прохождение туристских маршрутов по выбранным участкам водной поверхности. С позиции туристов в одних случаях - это активный отдых, направленный на совершенствование физических и духовных качеств, познание новой природной среды или обеспечение его экстремальных условий, хотя с научной точки зрения, детальное исследование понятия «отдых" дает нам возможность более глубокого понимания фундаментальности данной категории [1; 2]. В других случаях водный туризм - это стремление к спортивному совершенствованию в преодолении естественных препятствий, имеющихся в природной среде на водных маршрутах и дистанциях.

Степень развития водного туризма в конкретном регионе определяется строением гидрографической сети, относительной транспортной доступностью объектов и уровнем его популяризации среди населения. Прибайкалье в этом отношении имеет огромный рекреационно-туристский потенциал [3], способный развивать инфраструктуру туризма, к которой среди прочего мы относим и страхование. Данная дестинация представлена разнообразными природными ресурсами и имеет множество сильных сторон [4; 5]. На ее территории находится всемирно известное озеро Байкал, площадь акватории которого составляет 31,5 тыс. км ${ }^{2}$ и множество рек от малых до крупных, количество и общая протяженность которых представлена в табл. 1.

Таблица 1

Основные характеристики речной сети Иркутской области и Республики Бурятия

\begin{tabular}{|l|r|r|r|}
\hline & Количество рек & $\begin{array}{r}\text { Общая протяженность } \\
\text { рек, км }\end{array}$ & $\begin{array}{c}\text { Средняя плотность } \\
\text { речной сети, км/км }\end{array}$ \\
\hline Иркутская область & 65041 & 309355 & 0,26 \\
\hline Республика Бурятия & 32603 & 152186 & 0,43 \\
\hline
\end{tabular}

Составлено автором по данным ${ }^{1}$.

Заметим, что по протяжённости речной сети среди регионов Сибирского федерального округа Иркутская область и Республика Бурятия занимают соответственно 2 и 3 место $^{2}$. Густая речная сеть, ее характер и структура предопределили возможность разработать заинтересованными лицами около 30 востребованных водных маршрутов - от экологических до экстремальных разной степени сложности. При этом наибольший интерес представляют реки Баргузин, Верхняя Ангара, Витим, Селенга, Снежная, Утулик, Хара-Мурин. Туристов особо привлекают также некоторые участки рек Восточного Саяна - Иркута, Китоя, Белой, Оки, Уды, Ии, Гутары. Большие уклоны, наличие каньонов и скальных прижимов, перекатов и сложных порогов, извилистость рек и их полноводность привлекают не только любителей активного отдыха, экстремалов, но и организаторов соревнований по дисциплине «Спортивный туризм», заключающихся в прохождении спортивных туристских маршрутов с преодолением категорированных препятствий, а также спортсменов, стремящихся к участию в них. Так, анализ итоговых протоколов соревнований по спортивной дисциплине «Маршрут-водный (1-6 категория)», представленных Федерацией спортивного туризма России, показал, что за 2017 год на территории Прибайкалья было проведено 7 соревнований федерального уровня, в которых за период с июня по август приняло участие 57 человек (см. табл. 2).

\footnotetext{
${ }^{1}$ Вода России : науч.-попул. энцикл.. URL: http://water-rf.ru.

${ }^{2}$ Там же.
}

\section{Baikal Research Journal}


Таблица 2

Обшие данные о всероссийских соревнованиях по спортивной дисииплине "Марирут-водный (1-6 категория)", проведенных в 2017 году на территории Прибайкалья

\begin{tabular}{|c|c|c|c|c|}
\hline Статус соревнований & Дата проведения & Река & $\begin{array}{l}\text { Категория } \\
\text { сложности }\end{array}$ & $\begin{array}{l}\text { Численность } \\
\text { участников }\end{array}$ \\
\hline \multirow{3}{*}{ Чемпионат России, 2017} & $16.06-19.07 .2017$ & Онот & 6 & 8 \\
\hline & $06.08-25.08 .2017$ & Онот & 6 & 8 \\
\hline & $04.08-21.08 .2017$ & Китой & 6 & 12 \\
\hline \multirow{2}{*}{ Кубок России, 2017} & $07.07-23.07 .2017$ & $\begin{array}{c}\text { Жоммболок, } \\
\text { Ока }\end{array}$ & 5 & 8 \\
\hline & $14.07-30.07 .2017$ & $\begin{array}{c}\text { Жоомболок, } \\
\text { Урик }\end{array}$ & 5 & 8 \\
\hline Первенство России, 2017 & $21.06-14.07 .2017$ & Иркут & 2 & 5 \\
\hline $\begin{array}{l}\text { Всероссийские соревнования, } \\
2017\end{array}$ & $21.06-14.07 .2017$ & Иркут & 2 & 8 \\
\hline
\end{tabular}

Составлено автором по данным итоговых протоколов соревнований ${ }^{3}$.

Кроме этого, ежегодно проводятся соревнования регионального и муниципального уровня, традиционными из которых стали Открытый чемпионат Иркутской области по спортивному туризму на водных дистанциях «Лангатуй», Открытый чемпионат г.Иркутска по спортивному туризму в группе дисциплин «маршрут» и другие - они более массовые по числу участников, что можно видеть по данным, представленным в табл. 3.

Таблица 3

Общие данные о соревнованиях регионального и муниципального уровня по дисциплинал "Марирут-водный" и "Дистанция-водная", проведенных в 2017 году на территории Прибайкалья

\begin{tabular}{|c|c|c|c|c|}
\hline Статус соревнований & $\begin{array}{c}\text { Дата } \\
\text { проведения }\end{array}$ & Река & Дисциплина & $\begin{array}{l}\text { Количество } \\
\text { участников }\end{array}$ \\
\hline $\begin{array}{l}\text { Открытый чемпионат Иркут- } \\
\text { ской области по спортивному } \\
\text { туризму на водных дистанциях } \\
\text { «Лангатуй» }\end{array}$ & $03-04.06 .2017$ & Хара-Мурин & $\begin{array}{l}\text { Слалом } \\
\text { Эстафета }\end{array}$ & 120 \\
\hline $\begin{array}{l}\text { Чемпионат Иркутской области } \\
\text { по спортивному туризму на } \\
\text { водных дистанциях }\end{array}$ & 03.07 .2017 & Хара-Мурин & $\begin{array}{c}\text { Дистанция- } \\
\text { водная - ка- } \\
\text { тамаран } 2 \\
\text { Дистанция- } \\
\text { водная - } \\
\text { катамаран } 4\end{array}$ & 53 \\
\hline \multirow{3}{*}{$\begin{array}{l}\text { Открытый чемпионат г.Иркут- } \\
\text { ска, } 2017\end{array}$} & $08-14.06 .2017$ & Утулик & $\begin{array}{c}\text { Маршрут- } \\
\text { водный }\end{array}$ & 6 \\
\hline & $10-15.05 .2017$ & Вихоревка & $\begin{array}{c}\text { Маршрут- } \\
\text { водный }\end{array}$ & 10 \\
\hline & $15-21.06 .2017$ & $\begin{array}{c}\text { Гоуджекит, } \\
\text { Тыя }\end{array}$ & $\begin{array}{c}\text { Маршрут- } \\
\text { водный }\end{array}$ & 11 \\
\hline
\end{tabular}

Составлено автором по данным итоговых протоколов соревнований.

Как видно из данных табл. 3, всего в соревнованиях данного уровня приняли участие 200 человек - для страховщиков это фактический гарантированно-ми-

3 Федерация спортивного туризма России. URL: http://www.tssr.ru/main/spp/chempionat/ itogi/1906.

\section{Baikal Research Journal}


нимальный потенциал лишь части сегмента регионального рынка страхования туристов - водников.

Являясь разновидностью активного отдыха и признанным видом спорта, водный туризм предполагает значительные физические нагрузки и повышенный риск травматизма его участников: в походе возможны обострения хронических заболеваний или возникновение специфических рисков туристов, обусловленных наличием естественных источников опасности (сложный рельеф местности, труднопроходимые пороги, пороги-водопады, перекаты, водопады, прижимы и т.п.), неблагоприятными изменениями гидро- и метеоусловий и неправильными или неосторожными действиями самих туристов. В связи с этим высокую вероятность реализации приобретают риски несчастных случаев и болезней и риски утраты или повреждения имущества, используемого в походе (главным образом, экипировки и дорогостоящих средств сплава, к которым относят каяки, байдарки, рафты, катамараны и т.д). Часть рисков может быть минимизирована, если в походе участвуют туристы, прошедшие медицинский осмотр и специальную подготовку, в том числе физическую, осознающие степень опасностей и рисков, сопровождающих прохождение маршрута, использующие средства индивидуальной защиты и имеющие здоровый инстинкт самосохранения. Немалое значение имеют и знания о предстоящем маршруте и о его особенностях: так, для туристов Прибайкалья сотрудниками Главного управления МЧС России по Иркутской области и областной пожарно-спасательной службы разработаны интерактивные карты туристских маршрутов с их детальными характеристиками (продолжительность, категорийность, описание значимых участков, опасностей на них и рекомендаций по преодолению), что дает туристам-водникам возможность детального изучения планируемого маршрута и оценки уровня риска, связанного с его прохождением ${ }^{4}$.

Безопасность в туристском походе складывается из множества факторов, например, знаний и умений применять методы страховки при прохождении водных препятствий, наличия страховочного снаряжения, умений оказать первую помощь, наличия средств связи со службами спасения и т.п. Однако, если риск реализовался, то минимизация его финансовых последствий во многом зависит от наличия заранее организованной страховой защиты. Решение вопроса о необходимости страхования, объеме страхового покрытия и способе его приобретения зависит от целей прохождения маршрута (спортивный или рекреационный) и его организации (индивидуальный (одиночный) или групповой).

Начнем со спортивного туризма. В настоящее время, если прохождение водного туристского маршрута с преодолением категорированных препятствий или преодоление водной дистанции осуществляется в рамках участия в спортивных соревнованиях, то в соответствии с п.50 Правил вида спорта «Спортивный туризм», утвержденных Приказом Министерства спорта Российской Федерации от 22 июля 2013 г. № 571 (далее по тексту - Правила), «все участники туристской группы на время прохождения маршрута 5 и 6 категорий сложности должны иметь медицинскую страховку, включающую страхование рисков, связанных с прохождением маршрута в природной среде, а также проведение, при необходимости, поисково-спасательных и эвакуационных работ». Безопасность соревнований обеспечивается взаимодействием их организаторов со страховыми компаниями и спасательными службами. При этом каждый спортсмен во время прохождения маршрута «самостоятельно предпринимает все необходимые меры безопасности и несет полную ответственность за свои действия» (п. 53 указанных Правил). При наступлении страхового случая проводятся консультации с врачами неотложной

\footnotetext{
${ }^{4}$ Туристские маршруты на территории Иркутской области. URL: http://irkobl.ru/sites/tour/tur.
}

\section{Baikal Research Journal}

электронный научный журнал Байкальского государственного университета 
медицинской помощи и специалистами соответствующей страховой компании, и организаторы соревнований принимают решение о дальнейших действиях, вплоть до прекращения маршрута или эвакуации участника или группы.

Из этого можно сделать несколько важных выводов, предопределяющих особенности страхования спортсменов-водников.

Во-первых, организованные групповые спортивные маршруты высших категорий сложности обеспечиваются страховой защитой их участников практически в обязательном порядке. Такая обязательность определяется не юридическим фактом того, что законом на указанных в нем лиц возлагается обязанность страховать жизнь, здоровье или имущество других лиц, а существованием мер ответственности, возлагаемых на организаторов соревнований за необеспечение установленных требований. Статья 56 указанных Правил гласит: «Невыполнение требований по обеспечению безопасности во время проведения соревнований влечет за собой ответственность вплоть до отстранения от соревнований и спортивной дисквалификации». Таким образом, непредоставление потенциальным участником туристской группы страхового полиса означает фактическую невозможность включения его в состав группы, несмотря на то, что согласно п.2 ст.935 ГК РФ обязанность страховать свою жизнь или здоровье не может быть возложена на гражданина по закону.

Во-вторых, Правилами не определены объекты, подлежащие страхованию, не конкретизирован характер рисков, на случай которых должно осуществляться страхование, и указан слишком ограниченный рекомендуемый период страховой защиты. «Риски, связанные с прохождением маршрута в природной среде» очень емкая по содержанию, но весьма абстрактная по прочтению юридическая дефиниция, трактовать которую потенциальный страхователь может по-разному, исходя из собственного ощущения уровня опасности. Прохождение маршрута или преодоление дистанции, безусловно, основной и самый опасный этап проводимого мероприятия, но не единственный: на пути следования к месту проведения соревнований и обратно, при подготовке к старту и в процессе послефинишных сборов также возможны несчастные случаи, страхование от которых не менее актуально. Более того, обычаями делового оборота не предусмотрено использование в профессиональной и терминологической лексике словосочетания «медицинская страховка». Не используется оно и в законодательных актах. Согласно статьи 32.9 Федерального закона «Об организации страхового дела в Российской Федерации» от 27.11.1992 года № 4015-1, в Российской Федерации, кроме прочих, осуществляется медицинское страхование и страхование от несчастных случаев и болезней. При этом объектами медицинского страхования, согласно статьи 4 вышеуказанного закона, могут быть «имущественные интересы, связанные с оплатой организации и оказания медицинской и лекарственной помощи (медицинских услуг) и иных услуг вследствие расстройства здоровья физического лица или состояния физического лица, требующих организации и оказания таких услуг, а также проведения профилактических мероприятий, снижающих степень опасных для жизни или здоровья физического лица угроз и (или) устраняющих их». Поэтому так называемая разработчиками Правил вида спорта «спортивный туризм» "медицинская страховка» проведение поисково-спасательных и эвакуационных работ включать не может - только оплату их организации и оказания.

Более того, все граждане Российской Федерации, постоянно или временно проживающие в Российской Федерации иностранные граждане и лица без гражданства уже обеспечены гарантий бесплатного оказания медицинской помощи в рамках базовой и территориальной программы обязательного медицинского страхования за счет средств обязательного медицинского страхования. Таким обра-

\section{Baikal Research Journal}

электронный научный журнал Байкальского государственного университета 
зом, разработчики Правил вида спорта «Спортивный туризм» скорее всего, имели ввиду необходимость обеспечения страховой защиты спортсменов, осуществляемой в рамках добровольного медицинского страхования - оно дает возможность средствами страховой компании обеспечить транспортировку пострадавшего в медицинское учреждение, а в последующем и к месту проживания, оказание медицинской помощи в объемах, превышающих заложенные в программах ОМС, либо оказание медицинской помощи в специализированных или многопрофильных лечебных учреждениях, предоставляющих высококачественное медицинское обслуживание, а в особых случаях - пребывание родственников или репатриацию останков. Данный вид страхования в большей мере актуален для иностранных туристов, лиц, прибывших из отдаленных регионов, а также тех, кого не устраивает объем и качество помощи, оказываемой в рамках обязательного медицинского страхования. Поэтому в данном случае считаем необходимым провести терминологическую корректировку используемых в анализируемом правовом источнике страховых понятий.

Оправданным дополнением к медицинскому страхованию, либо его альтернативой, может стать страхование от несчастных случаев и болезней, поскольку кроме риска причинения вреда здоровью, оно включает покрытие на случай смерти туриста в результате несчастного случая или болезни, а также может предусматривать компенсацию расходов на медико-социальную, психологическую реабилитацию, санаторно-курортное лечение и протезирование в случае получения застрахованным серьезных травм. Примечателен в этом случае опыт проведения межрегиональных и всероссийских официальных спортивных соревнований по рафтингу, участие в которых возможно только при наличии полиса страхования жизни и здоровья от несчастных случаев 5 .

В-третьих, Правилами не установлены требования к минимальному размеру страховой суммы, на которую должен быть заключен договор страхования, что может привести к недооценке туристом возможного объема непредвиденных затрат, связанных с реализацией риска, либо к использованию им юридически-формального подхода к заключению страхового договора: для получения допуска к участию в соревнованиях возможно страхование на условиях минимальной страховой суммы, которая позволит минимизировать страховые платежи, но не даст возможность обеспечить должное страховое покрытие, достаточное для покрытия возникших затрат.

B-четвертых, требования по обеспечению страховой защиты не устанавливаются в отношении участников водных соревнований на маршрутах I-IV категорий сложности и участвующих в дисциплинах водной дистанции, хотя для этих туристов риски не менее актуальны. Для них решение о страховании - это результат собственной заинтересованности в минимизации сопутствующих рисков или выполнение одного из условий организаторов соревнований по допуску к участию в них. Особенности страхования спортсменов, ситуация на данном сегменте страхового рынка Иркутской области и факторы его развития были достаточно подробно представлены нами ранее [6]. Смеем утверждать, что в полной мере результаты проведенного ранее исследования распространяются и на водный туризм спортивных достижений: спортивные дисциплины «Маршрут водный (1-6 категория)», «Дистанция водная - каяк», «Дистанция водная - байдарка», «Дистанция водная - катамаран 2», «Дистанция водная - катамаран 4», согласно

${ }^{5}$ Положение о межрегиональных и всероссийских официальных спортивных соревнованиях по рафтингу на 2017 год. Номер-код вид спорта: 1740001411Я : утв. Минспортом России 23.12.2016, Общероссийской общественной организацией «Федерация рафтинга России» 25.11.2016. П. 2, разд. III. URL: http://www.consultant.ru/document/cons_doc_LAW_219453.

\section{Baikal Research Journal}

электронный научный журнал Байкальского государственного университета 
Всероссийского реестра видов спорта относятся к признаваемому виду спорта, включенному в раздел развиваемых на общероссийском уровне ${ }^{6}$.

Стоит заметить также, что доля лиц, выбирающих водный туризм не ради достижения спортивных результатов, а по совершенно иным, весьма разнообразным причинам (от природно-познавательной до стремления к экстремальным условиям обитания) все же больше. $K$ сожалению, в настоящее время не ведется статистический учет лиц, совершающих походы по водным маршрутам, но, оценивая число предложений об участии в водных туристских походах, количество набираемых в них участников, а также количество размещаемых в общедоступных источниках отчетов о водных походах, смеем утверждать, что это так. Для таких туристов страхование не менее актуально (особенно если признается недостаточным уровень физической и психо-эмоциональной подготовки участника сплава), и при этом они имеют абсолютную самостоятельность как в принятии решения об обеспечении себя страховой защитой, основанном на осознании личной самоответственности за возможные риски и их последствия, так и в выборе страховых программ и способе их приобретения (самостоятельно в офисе продаж, on-line на сайте страховой компании, обращаясь к услугам страховых агентов или централизованно через организатора тура или похода). Основные схемы страхования туристов, их преимущества и недостатки достаточно подробно описаны в научной литературе [7]. Мы же отметим, что комплексная страховая защита, формируемая на время похода, может включать в себя:

- страхование от несчастных случаев и болезней;

- добровольное медицинское страхование;

- страхование ответственности перед третьими лицами на время похода;

- страхование туристского и спортивного инвентаря, экипировки и иного имущества, представляющего особую ценность для туриста (на условиях «специального» договора, предусматривающего страхование имущества по временному месту нахождения или на условиях «общего» договора на время нахождения имущества на месте постоянного хранения).

Дополнительно для лиц, приезжающих в Прибайкалье из других регионов, возможно:

- страхование багажа на время следования к месту отдыха и обратно;

- страхование расходов, возникших вследствие задержки рейса, отмены поездки или изменения сроков пребывания в поездке;

- страхование риска возникновения дополнительных расходов выезжающих за пределы региона постоянного проживания.

Базовым видом страхования туристов, по нашему мнению, является страхование от несчастных случаев. В настоящее время все чаще среди заинтересованных лиц обсуждается необходимость включения в объем его покрытий опции «организация и проведение поисково-спасательных работ, в том числе с использованием малой авиации» - это имеет особую актуальность для тех туристов, кто совершает походы в труднодоступные местности или с ожидаемой высокой технической сложностью локальных и протяженных препятствий. Для предоставления такой услуги страховщик должен заключить договор на проведение поисково-спасательных работ с организацией, имеющей аварийно-спасательные средства, в том числе парк соответствующей авиации (главным образом, легкие вертолеты [8, с. 17]), укомплектованный штат спасателей и прошедшей соответствующую аттестацию. На территории Прибайкалья в настоящее время одновременного выполнения этих

${ }^{6}$ Об утверждении порядка признания видов спорта, спортивных дисциплин и включения их во Всероссийский реестр видов спорта и порядка его ведения [Электронный ресурс] : приказ Минспорта России от 02.09.2013 г. № 702 // СПС «КонсультантПлюс».

\section{Baikal Research Journal}

электронный научный журнал Байкальского государственного университета 
трех условий не может обеспечить ни один поставщик услуг из числа коммерческих предприятий. Дело в том, что поисково-спасательные работы являются разновидностью аварийно-спасательных работ, осуществляемых аварийно-спасательными службами и аварийно-спасательными формированиями. При этом согласно ст. 10 Федерального закона от 22.08.1995 № 151-Ф3 «Об аварийно-спасательных службах и статусе спасателей», «все аварийно-спасательные службы, аварийно-спасательные формирования подлежат обязательной регистрации», а согласно ст. 12 - и аттестации в порядке, устанавливаемом Правительством Российской Федерации. Не прошедшие аттестацию службы и формирования к обслуживанию организаций по договору не допускаются и к проведению аварийно-спасательных работ не привлекаются (п. 2 ст. 12 указанного Закона). Спасателями также признаются лишь граждане, подготовленные и аттестованные на проведение аварийно-спасательных работ.

Анализ отчетов МЧС России о спасательных формированиях в субъектах Российской Федерации - Иркутской области и республике Бурятия - показал, что на территории Прибайкалья по состоянию на 01.01.2018 года единственным аттестованным профессиональным поисково-спасательным формированием, допущенным к ведению поисково-спасательных работ, является ФГКУ «Байкальский поисково-спасательный отряд МЧС России» ${ }^{7}$. Именно на него возлагается задача по оказанию своевременной квалифицированной помощи туристам, оказавшимся в условиях чрезвычайной ситуации.

Таким образом, в условиях отсутствия в регионе соответствующих страховых продуктов, направленных на защиту имущественных интересов застрахованных лиц, связанных с осуществлением поисково-спасательных работ в районах туристского маршрута, туристские группы и отдельные туристы должны быть особо заинтересованы в выполнении рекомендации МЧС России по регистрации маршрута в соответствующих подразделениях МЧС. В частности, в Иркутской области - в ОГКУ «Аварийно-спасательная служба Иркутской области» или «Байкальском поисково-спасательном отряде МЧС России». Это дает возможность поисково-спасательной службе в целях обеспечения безопасности туристов осуществлять контроль за прохождением маршрута с отслеживанием контрольных сроков и времени возвращения, своевременно информировать туристов о реальных и прогнозируемых погодных условиях на маршруте и в случае необходимости своевременно оказать квалифицированную помощь, направленную на поиск и спасение пострадавших.

Что касается других видов страхования, то они являются традиционными для страхового дела и не имеют объективных препятствий для их осуществления. Принципиальным фактором их развития может стать уровень спроса со стороны страхователей. Выбор ими видов страхования и перечня страхуемых рисков зависит от результатов оценки туристом уровня опасности, ожидаемых финансовых потерь и возможностей по оплате страховых взносов. Немаловажным фактором является и ментальная готовность человека к приобретению страховой услуги [9]. Основную роль в моделировании ментальной готовности физически активного населения к приобретению страховых услуг на время совершения туристских походов, по нашему мнению, должны взять на себя страховые организации. Осознание страховщиками социальной ответственности и необходимость решения тактических задач, предопределяет возможность достижения ими основной цели организации страхового дела. Основными мероприятиями по развитию страхования в сфере водного туризма в Прибайкалье, по нашему мнению, должны стать:

${ }^{7}$ Аттестованные аварийно-спасательные службы и аварийно-спасательные формирования // МЧС России. URL: http://www.mchs.gov.ru/activities/Attestacija/Attestovannie_avarijno_spasatelnie_sluzb.

\section{Baikal Research Journal}

электронный научный журнал Байкальского государственного университета 
1. Активное участие страховых организаций в общественных мероприятиях, проводимых Агентством по туризму Иркутской области, Республиканским агентством по туризму Республики Бурятия, Областной общественной организацией «Федерация спортивного туризма Иркутской области», Федерацией спортивного туризма и альпинизма республики Бурятия с целью популяризации страхования, формирования положительного образа страховых организаций.

2. Построение страховыми компаниями внешних коммуникаций с субъектами туристского пространства, способными оказать влияние на формирование ментальной готовности туристов к обеспечению себя страховой защитой:

a) с общественными организациями сферы туризма. В настоящее время в их число входят: Сибирская Байкальская ассоциация туризма, Иркутская региональная ассоциация турбизнеса, Межрегиональная ассоциация событийного туризма Сибири, Иркутская региональная общественная организация развития детского и молодежного туризма «Юность без границ», Федерация спортивного туризма Иркутской области;

б) с туристско-информационными центрами, которые могли бы размещать информацию о действующих на рынке туристского страхования страховых компаниях и предлагаемых ими продуктах. В настоящее время основным таким центром является МБУ г. Иркутска «Информационно-туристская служба г. Иркутска»;

в) с туристическими компаниями - это самый представительный сегмент инфраструктуры туристского страхования (см. табл. 4), субъекты которого напрямую заинтересованы в обеспечении безопасности туристов, в том числе посредством страхования (см. ст. 14 Федерального закона «Об основах туристской деятельности в Российской Федерации» от 24.11.1996 № 132-ФЗ).

Таблица 4

Общие сведения о количестве туроператоров и турагентов, осуществляющих деятельность на территории Иркутской области и Республики Бурятия по состоянию на 20.01.2018 2.

\begin{tabular}{|l|r|rr|}
\hline & Количество туроператоров & Количество турагентов \\
\hline Иркутская область & 120 & 42 \\
\hline Республика Бурятия & 21 & 7 \\
\hline
\end{tabular}

Составлено автором по данным ${ }^{8}$.

г) с туристическими клубами, в центре интересов которых стоит водный туризм, включая рафтинг и каякинг, а также организация сплавов по рекам. Самыми представительными и наиболее активно развивающимися являются турклубы г. Иркутска: «SibRaft», «КОЙОТ», «Иркут». Участниками таких клубов являются туристы, имеющие практические представления об уровне ожидаемого в походе риска, поэтому они более избирательны и вполне конкретны в ожиданиях от страховых услуг, а также способны оказать влияние на формирование страховой культуры тех, кто только приобщается к туризму.

Цели внешних коммуникаций, их место и роль в бизнес-процессе достаточно подробно описаны в научной литературе [10]. Рассматривались также и вопросы информационного воздействия на сознание потребителей [11]. Отметим лишь, что для страховых организаций приоритетными задачами является конвергенция, формирование у потенциальных страхователей ценностно-мотивационного отношения к безопасности, формирование понимания роли и значимости страхования

8 Единый федеральный реестр туроператоров. URL: https://www.russiatourism.ru/operators ; Tурпомощь : база данных турагентств. URL: https://reestr.tourpom.ru/search.php.

\section{Baikal Research Journal}

электронный научный журнал Байкальского государственного университета 
в минимизации рисков, повышение престижа человека, стремящегося защитить свои имущественные интересы.

Участие страховых организаций в образовательных проектах, деятельности туристических школ и школ подготовки инструкторов-проводников с целью реализации просветительской функции, формирования основных знаний о видах страхования туристов и существующих страховых продуктах. Одной из форм такого участия могло бы стать включение в тематический план обучения слушателей занятий по страхованию и страховому делу. Основными партнерами в этом видим Школу подготовки инструкторов-проводников Прибайкалья, организованную Федерацией спортивного туризма Иркутской области и специализированную туристическую школу г. Иркутска «Школа выживания «КОЙОТ».

Привлечение страховыми компаниями в качестве страховых агентов по продаже полисов страхования туристов организаторов водных походов, инструкторов-проводников и постоянных членов туристических клубов - это могло бы обеспечить более оперативную информированность планирующих совершить поход о способах страховой защиты, вариантах страховых программ и их преимуществах, а приобретение полиса сделало максимально доступным и удобным.

Адаптация существующих программ страхования туристов под интересы лиц, занимающихся именно водным туризмом и создание на их основе и «коробочных» продуктов с простым и понятным для клиента набором условий, и индивидуальных программ. Использование в работе со страхователями принципов клиентоориентированности и транспарентности - условий, необходимых для формирования лояльности клиентов. Основные, наиболее перспективные направления развития клиентских отношений между страхователями и страховщиками были представлены нами ранее [12], но считаем, что они вполне актуальны и для рынка страхования туристов.

Оптимизация взаимоотношений страховых компаний и организаций, принимающих участие в оказании помощи пострадавшим в результате страхового случая туристам - поисково-спасательным формированием, компаниями, предоставляющими услуги по медицинской транспортировке пострадавших, медицинскими учреждениями и т.д. с целью повышения скорости и качества оказываемых застрахованным лицам услуг.

В конечном счете, выполнение страховщиками комплекса мер, направленных на развитие страхования туристов, будет способствовать повышению безопасности водного туризма, являющегося одним из стратегических секторов туристского рынка Прибайкалья.

\section{Список использованной литературы}

1. Пожитной Н. М. Основы теории отдыха / Н. М. Пожитной, В. М. Хромешкин. СПб. : Изд-во СПб. ун-та управления и экономики, 2011. - 180 с.

2. Суходолов А. П. Отдых как социально-экономическая и философская категория / А. П. Суходолов // Известия Иркутской государственной экономической академии (Байкальский государственный университет экономики и права). - 2012. — № 6 (86). C. $173-174$.

3. Винокуров М. А. Экономика Иркутской области. В 6 т. / М. А. Винокуров, А. П. Суходолов ; Байкальский гос. ун-т экономики и права. - Иркутск : Изд-во БГУЭП, 2004. T. $4 .-246$ с.

4. Даниленко Н. Н. Влияние социальных функций туризма на устойчивое развитие региона (на примере Прибайкалья) / Н. Н. Даниленко, Н. В. Рубцова // Известия Иркутской государственной экономической академии (Байкальский государственный университет экономики и права). - 2012. - № 6 (86). - С. 47-53.

\section{Baikal Research Journal}

электронный научный журнал Байкальского государственного университета 
5. Даниленко Н. Н. Туризм и устойчивое развитие региона: социальный и институциональный аспекты / Н. Н. Даниленко, Н. В. Рубцова. - Иркутск : Изд-во БГУЭП, 2013. 157 c.

6. Степанова М. Н. Проблемы и перспективы развития страхования спортсменов от несчастных случаев: региональный аспект / М. Н. Степанова // Будущее российского страхования: оценки, проблемы, точки роста : сб. тр. XVII междунар. науч.-практ. конф. Ростов н/Д. : Изд-во Южного федер. ун-та, 2016. - С. 243-249.

7. Усманова К. М. Основные схемы страхования туристов: преимущества и недостатки / К. М. Усманова // Торговля, предпринимательство и право. - 2016. — № 1. - С. 81-85.

8. Пискулова П. Культура страхования и практика спасения / П. Пискулова // SKI INDUSTRY. - 2017. - № 3. - C. 16-23.

9. Степанова М. Н. Ментальная готовность как фактор формирования спроса на страховые услуги / М. Н. Степанова // Страхование в системе финансовых услуг в России: место, проблемы, трансформация. В 2 т. : сб. тр. XVIII Междунар. науч.-практ. конф., Кострома, 7-9 июня 2017 г. / под ред. Е. В. Злобина, Р. Т. Юлдашева. - Кострома : Изд-во Костром. гос. ун-та, 2017. - Т. 2. - С. 283-287.

10. Демина И. Н. Место и роль коммуникации в бизнес-процессах / И. Н. Демина // Известия Иркутской государственной экономической академии (Байкальский государственный университет экономики и права). - 2012. - № 2 (82). - С. 202-206.

11. Колесникова Т. В. «Идея о страховании» как способ обеспечения конкурентоспособности российской страховой организации на либерализованном страховом рынке / Т. В. Колесникова // Известия Иркутской государственной экономической академии. 2013. - № 4. - С. 33-36.

12. Степанова М. Н. Развитие системы досудебного урегулирования страховых споров / М. Н. Степанова // Известия Иркутской государственной экономической академии. - 2016. — Т. 26, № 4. — С. 622-628. - DOI : 10.17150/2500-2759.2016.26(4).622-628.

\section{References}

1. Pozhitnoi N. M., Khromeshkin V. M. Osnovy teorii otdykha [Basics of recreation theory]. Publishing house of Saint-Petersburg university of management and economics Publ., 2011. $180 \mathrm{p}$.

2. Sukhodolov A. P. Recreation as socioeconomic and philosophical category. Izvestiya Irkutskoi gosudarstvennoi ekonomicheskoi akademii $=$ Bulletin of Irkutsk State Economics Academy, 2012, no. 6 (86), pp. 173-174. (In Russian).

3. Vinokurov M. A., Sukhodolov A. P. Ekonomika Irkutskoi oblasti [Economy of Irkutsk Oblast]. Irkutsk, Baikal State University of Economics and Law Publ., 2004, vol. 4. 246 p.

4. Danilenko N. N., Rubtsova N. V. Impact of social functions of tourism on region's sustainable development (by the example of Baikal region). Izvestiya Irkutskoi gosudarstvennoi ekonomicheskoi akademii = Bulletin of Irkutsk State Economics Academy, 2012, no. 6 (86), pp. 47-53. (In Russian).

5. Danilenko N. N., Rubtsova N. V. Turizm i ustoichivoe razvitie regiona: sotsial'nyi $i$ institutsional'nyi aspekty [Tourism and sustainable regional development: social and institutional aspects]. Irkutsk, Baikal State University of Economics and Law Publ., 2013. 157 p.

6. Stepanova M. N. Problems and prospects of sportsmen's insurance development against accidents: the regional aspect. Budushchee rossiiskogo strakhovaniya: otsenki, problemy, tochki rosta. Materialy XVII mezhdunarodnoi nauchno-prakticheskoi konferentsii, Rostov na Donu, 2016 g. [The future of Russian insurance: assessments, problems, growth points. Materials XVII of International Research Conference, Rostov-on-don, Southern Federal University Publ., 2016, pp. 243-249. (In Russian).

7. Usmanova K. M. Basic insurance schemes for tourists: advantages and disadvantages. Torgovlya, predprinimatel'stvo $i$ pravo = Trade, Business and Law, 2016, no. 1, pp. 81-85. (In Russian).

8. Piskulova P. Culture of insurance and rescue practice. SKI INDUSTRY, 2017, no. 3, pp. 16-23. (In Russian).

9. Stepanova M. N. Mental willingness as a factor of demand formation for insurance services. In Zlobin E. V., Yuldashev R. T. Strakhovanie $v$ sisteme finansovykh uslug $v$ Rossii: mesto, problemy, transformatsiya. Materialy XVIII mezhdunarodnoi nauchno-prakticheskoi konferen-

\section{Baikal Research Journal}


tsii, Kostroma, iyunya 2017 g. [Insurance in Financial Service System in Russia: Place, Problems, Transformation. Materials XVIII of International Research Conference, Kostroma, June 2017]. Kostromskoi gosudarstvennyi universitet Publ., 2017, vol. 2, pp. 283-287. (In Russian).

10. Demina I. N. Place and role of communication in business processes Izvestiya Irkutskoi gosudarstvennoi ekonomicheskoi akademii = Bulletin of Irkutsk State Economics Academy, 2012, no. 2 (82), pp. 202-206. (In Russian).

11. Kolesnikova T. V. The «idea of insurance» as a way of maintaining the russian insurance organization's competitiveness on the liberalized insurance market. Izvestiya Irkutskoi gosudarstvennoi ekonomicheskoi akademii = Bulletin of Irkutsk State Economics Academy, 2013, no. 4, pp. 33-36. (In Russian).

12. Stepanova M. N. Development of the pre-trial settlement system for insurance disputes. Izvestiya Irkutskoi gosudarstvennoi ekonomicheskoi akademii = Bulletin of Irkutsk State Economics Academy, 2016, vol. 26, no. 4, pp. 622-628. DOI: 10.17150/25002759.2016.26(4).622-628. (In Russian).

\section{Информация об авторе}

Степанова Марина Николаевна - кандидат экономических наук, доцент, кафедра «Страхование и управление рисками», Байкальский государственный университет, 664003, г. Иркутск, ул. Ленина, 11, e-mail: emarina77@list.ru.

\section{Author}

Marina N. Stepanova - PhD in Economics, Associate Professor, Chair of Insurance and Risk Management, Baikal State University, 664003, 11 Lenin St., Irkutsk, e-mail: emarina77@ list.ru.

\section{Для цитирования}

Степанова М. Н. Водный туризм в Прибайкалье: вопросы организации страховой защиты туристов / M. Н. Степанова // Baikal Research Journal. - 2018. — T. 9, № 1. — DOI : 10.17150/2411-6262.2018.9(1).3.

\section{For Citation}

Stepanova M. N. Water Tourism in Baikal Region: Issues on Organization of Tourist Insurance Coverage. Baikal Research Journal, 2018, vol. 9, no. 1. DOI: 10.17150/24116262.2018.9(1).3. (In Russian).

\section{Baikal Research Journal}

